\title{
Analysis of Macrobenthic Communities in a Post-Mining Sulphur Pit Lake (Poland)
}

\author{
Aneta Bylak ${ }^{1}\left[\right.$ [ Wojciech Rak ${ }^{1} \cdot$ Magdalena Wójcik $^{1} \cdot$ Ewa Kukuła $^{2} \cdot$ Krzysztof Kukuła $^{1} \mathbb{C}$
}

Received: 19 January 2019 / Accepted: 31 July 2019 / Published online: 6 August 2019

(C) The Author(s) 2019

\begin{abstract}
The objective of the study was to define the primary environmental factors affecting the composition of the macrobenthic community in an abandoned open cast sulphur mine pit lake that had been filled with water from a nearby river. We investigated habitats at various depths and the macrobenthic communities; samples were collected by scuba divers. Although rush and submerged vegetation in the subsaline pit lake was abundant and provided potentially good habitat conditions for mayflies, caddisflies, coleopterans, or damselflies, the native insects were scarce. The taxa do not have many representatives in waters with elevated salinity, so those present in the Machów pit lake were mainly euryhaline species. Chironomids were the most abundant macroinvertebrates in shallower zones, whereas non-native zebra mussels were the quantitatively dominant taxon in deep-water zones. Moreover, these non-native mussels were the dominant biomass of invertebrates at all sites in all seasons. The current composition of the invertebrate assemblage was probably primarily determined by the salinated water, which limited the abundance of native species and gave non-native species an edge.
\end{abstract}

Keywords Aquatic invertebrates $\cdot$ Artificial lake $\cdot$ Chelicorophium curvispinum $\cdot$ Dreissena polymorpha $\cdot$ Ecological restoration · Open cast mine

\section{Introduction}

Open cast mining is one of the most dramatic ways through which humans impact the natural environment. The shape of the open cast mine pits is largely determined by the geological setting (i.e. kind of mined mineral, shape of the deposit, properties of the host rock), and by geomechanical safety requirements (Geller et al. 2013). A common method of reclaiming open cast mine pits is the creation of artificial lakes (Barker et al. 2004; de Lange et al. 2018). Exhausted pits are transformed into pit lakes (i.e. post-mining water

Electronic supplementary material The online version of this article (https://doi.org/10.1007/s10230-019-00624-2) contains supplementary material, which is available to authorized users.

Aneta Bylak

abylak@ur.edu.pl

1 Department of Ecology and Environmental Monitoring, University of Rzeszow, Zelwerowicza 4, 35-601 Rzeszow, Poland

2 Department of Agrobiology and Environmental Protection, University of Rzeszow, Zelwerowicza 4, 35-601 Rzeszow, Poland bodies) though artificial flooding or by allowing the pits to fill naturally through hydrological processes such as precipitation and groundwater infiltration (Gammons et al. 2009; Żurek et al. 2018). Sometimes the bottom and shores of the designed lake are transformed; in such cases, the bottom is at least partially levelled, and then the shores are profiled to resemble a natural water body (Geller et al. 2013; Schultze et al. 2010).

A flooded post-exploitation pit is an ecosystem in which processes begin de novo, including all of the ecological assemblages (plankton, benthos, nekton) (Marszelewski et al. 2017; Ruhí et al. 2009). In a developing ecosystem, random factors can be very important, and a developing aquatic ecosystem is initially colonized by various species that can further modify the environment. The final qualitative and quantitative structure of the assemblage is often largely determined by the pioneer colonisers, which either facilitate the establishment of other species through changes in the habitat, or monopolise the area by preempting the space (Krebs 2001; Paine 1994). Nonetheless, it is the abiotic parameters, such as water quality, that determine if organisms can colonise the lake or not (Luek and Rasmussen 2017; Lund and McCullough 2011). 
Pit lakes are generally not very deep but have an uneven bottom and steep shores. Therefore, the littoral zone is limited (de Lange et al. 2018). Although the invertebrate fauna somewhat resemble natural limnic assemblages (Dumnicka and Galas 2006), the structure of the assemblage is frequently determined by the chemical composition of the water (Barker et al. 2004; Żurek 2006).

The groundwater in the area of the Machów pit lake contains $\mathrm{H}_{2} \mathrm{~S}$ (Gołda et al. 2006), such that $\mathrm{H}_{2} \mathrm{~S}$ concentrations in the bottom of the Machów mine reached up to $300 \mathrm{mg} \mathrm{L}^{-1}$. Therefore, the water could not be used to fill the designed pit lake.

After excavation ceased in the Machów mine, an intensive drainage system was designed and maintained until the bottom of the pit was sealed. Then the drainage water in the pit was desulphurised and discharged to the nearby Vistula River (Gołda et al. 2006). After that, the only logical source of water that would permit the relatively fast filling of the lake was the Vistula River, flowing at a distance of 200-300 m from the pit. Water in the Vistula River, however, has an elevated salinity (up to $700 \mathrm{mg} \mathrm{L}^{-1}$ in the first flooding phase) caused by contaminants-mainly due to water from the upriver Silesia region, where there are numerous hard coal mines. There were no other significant contaminants associated with the salinity, and the amount of nutrients in the Vistula River water was relatively small (Dąbal and Marciniak-Kowalska 2011).

For comparison, in the 19th century, the chloride concentration in the unpolluted Vistula River was $5.7 \mathrm{mg} \mathrm{L}^{-1}$ (Olszewski 1871). In the 1930s, 90\% of the chloride concentration and $80 \%$ of the sulphate concentration in the Vistula River was due to the discharge of highly saline mine water to the Vistula or its tributaries (Kułakowski 1994). Currently, the salinity in the Vistula River and Machów pit lake is simi-

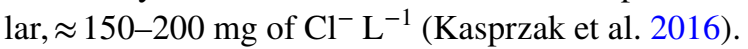

Unfortunately, it was difficult to find alternatives to using water from the Vistula River. Reclamation of areas of former open pit mines involves not only economic costs (European Commission 2000). There are also ecological, because energy is needed for remediation and materials have to be brought from somewhere else. One environmental damage cannot be replaced with others. This results in a limit on reasonable reclamation efforts (Mborah et al. 2016; Mishra et al. 2012).

On a regional scale, open pits can be numerous or occupy a fairly large area (McCullough and Van Etten 2011). This results in the need for effective reclamation of pits (Geller et al. 2013). Reclamation in which invertebrate fauna inhabit water-filled sulphur open pits are rare on a global scale (Dumnicka and Galas 2006).

This study involved analysing the ecological effects of flooding of the open cast mine pit with water from the nearby river. The analyses were particularly based on benthic invertebrates because they are widely recognised as a good indicator of freshwater habitat quality (Poikane et al. 2016). The objective of this study was to define the primary environmental factors affecting the composition of the macrobenthic community in the pit lake. We attempted to determine: (1) the taxonomic and trophic structure of the lake's invertebrate assemblage, and (2) what could be learned by analysing the structure of the benthic invertebrate assemblage in this pit lake?

\section{Materials and Methods}

\section{Study Area}

The Machów sulphur mine $\left(50^{\circ} 32^{\prime} 12^{\prime \prime} \mathrm{N} ; 21^{\circ} 38^{\prime} 07^{\prime \prime} \mathrm{E}\right.$; south-eastern Poland), together with the plant, was constructed in 1964-1970. Open cast exploitation of a rich deposit of sulphur started in 1969. From then until 1992, about $280 \mathrm{Mm}^{3}$ of overburden was removed, about $55.8 \mathrm{Mm}^{3}$ of sulphur ore was recovered, and about $11.1 \mathrm{Tg}$ of refined sulphur was produced (Siwik-Ziomek et al. 2018; Szmuc and Madej 2011). The Machów open pit had an area of 460 ha and a depth of 70-110 m (Dąbal and Marciniak-Kowalska 2011). After the open cast sulphur mine closed, the waste dumps were removed, and post-refining waste was deposited on the lowest level. The scarps of the open pit were then profiled, and the bottom of the future water body was sealed with an isolation layer ( $25 \mathrm{~m}$ of cracovian loam) that separated the basin from the post-refining waste and mineralised water from the Neogene horizon (with free $\mathrm{H}_{2} \mathrm{~S}$ ) (Felter et al. 2017). The shores of the water body were strengthened to protect them against erosion. Canals were constructed to connect the water body with the Vistula River and permit periodic mutual water exchanges between the river and pit lake (Żurek 2013). In spring 2009, the water body was completely filled. The resulting recreational water reservoir has an area of 455 ha and a maximum depth of $42 \mathrm{~m}$. Its average depth is $22 \mathrm{~m}$, its total volume is $111.2 \mathrm{Mm}^{3}$, and the length of the shoreline is $\approx 10 \mathrm{~km}$ (Fig. 1).

\section{Sampling Design}

This study was conducted in 2013. Using the bathymetry data (Machów Diving Base), four sites along a transect line were designated for sample collection, linking zones that had contrasting habitat conditions (a scuba diving benthic transect sampling methodology; Pardo 2014). The transect connected the lake shores with the centre, and was determined based on the sampling and safety procedures. We collected samples at four depths: $0.5-0.8$ (site 1), 4-5 (site 2), 10-12 (site 3), and 18-20 m (site 4). Samples were collected three times: in spring (May), summer (August), and autumn 
Fig. 1 Map of the Machów pit lake with the water and benthic sampling locations (rectangles; site 1-4); numbers-depths in metres (generalized bottom bathymetry, according to the Machów Diving Base)

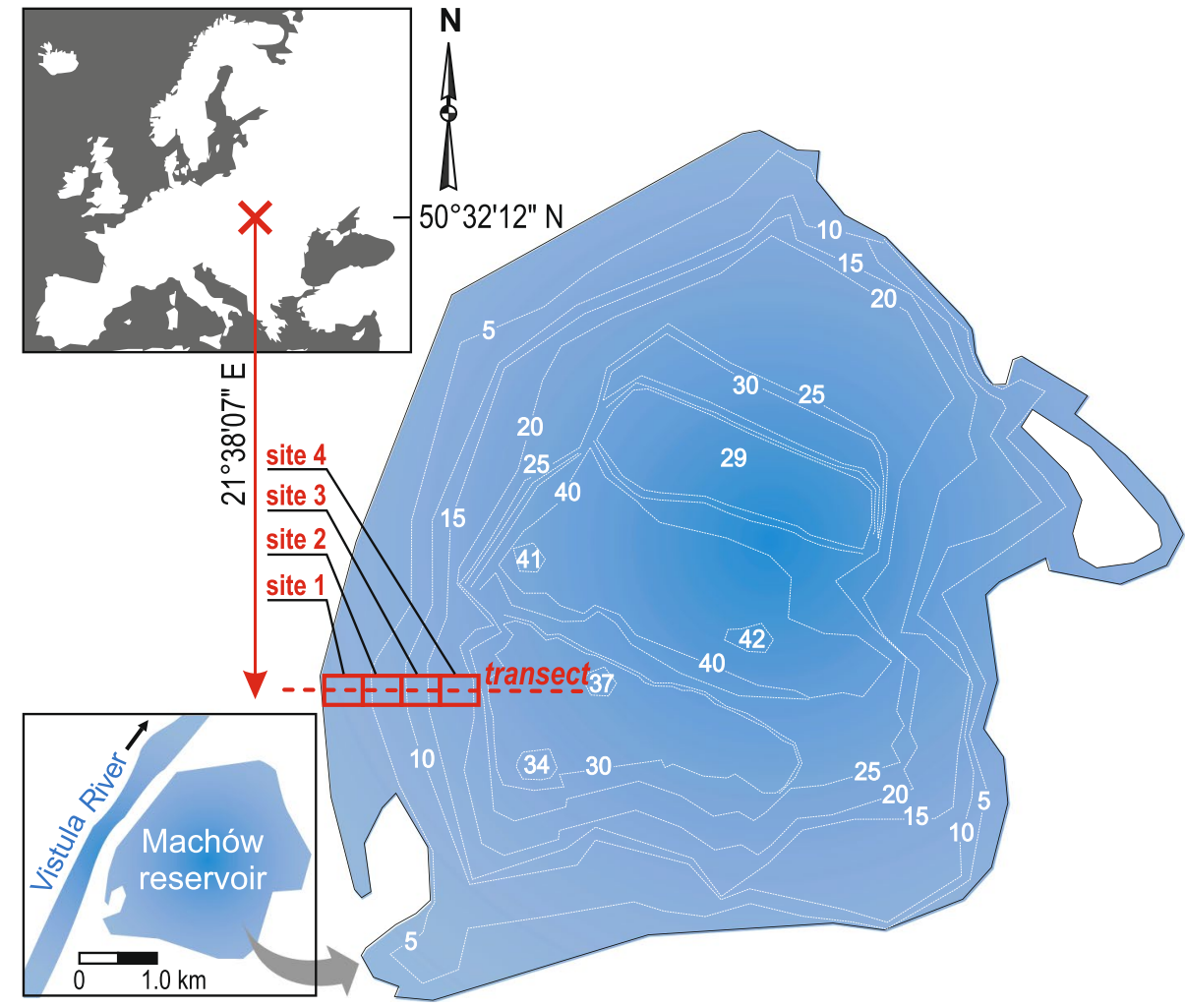

(November). Samples were taken on three consecutive days in each season. In our study, water and benthic samples were collected by scuba divers. Benthic samples were collected from the bottom surface, including the surface of submerged macrophytes. Although quantitative sampling methods vary with habitat and sediment type, divers can usually obtain high quality samples because they can position the samplers slowly and with care (Fleeger et al. 1988).

The presence of an underwater investigator also permitted us to obtain important insights into the characteristics of the site and aided in the practical aspects of sampling (Fleeger et al. 1988; Pardo 2014). The areas covered by different particle size fractions (e.g. stones, gravel, sand) and the percentage of each fraction in the bottom substrate were estimated. The substrate composition was estimated as the percentage of the area covered by the different particle size fractions. Five fractions of the bottom substrate were distinguished, namely: stones $(>16 \mathrm{~mm})$, gravel (16-2 mm), sand (<2 mm) (Bain et al. 1985), clay, and broken shells (Dreissena sp.). The scuba divers used folded rulers for the designation of squares of $0.5 \times 0.5 \mathrm{~m}$. The aquatic macrophyte vegetation was also surveyed and the most abundant species were identified. The abundance of macrophytes, as well as the amount of woody debris, organic matter, and fine sediments, were evaluated using a 5-level scale (0-4), where 0 means-lack, and 4-very numerous. The light intensity was expressed in a 4-level scale, based on the rationale that light decreases in a monotonic manner from surface to depth (Polunin 2008). All scuba divers, however, were unanimous in their assessment that at each sampling date, the light reached a depth of $20 \mathrm{~m}$, and probably much deeper. Therefore, based on a four-level scale, a ' + ' rating was awarded for the depth of $20 \mathrm{~m}$ (site 4), and it increased by one point for subsequent lower depths, until a depth of $0.6-0.8 \mathrm{~m}$ (site 1), where the value ' ++++ ' was determined (Table 1 ).

Scuba divers measured water temperature under at each sampling site by means of a submerged thermometer and by reading temperature at a given depth for several minutes after immersion. For further analysis, sample containers $(\approx 1500 \mathrm{~mL})$ were filled with water. Before diving, the air was vacuumed out from the virgin plastic containers. Then, they were opened underwater at a given depth, filled, and closed underwater. Water samples were processed on the shore (multiparameter sonde 6600 V2, YSI Incorporated, Yellow Springs, Ohio, USA; multimeter HQD40, Hach Lange GmbH, Düsseldorf, Germany; spectrophotometer LF300, Slandi, Sp. z o.o., Michałowice, Poland). The following parameters were measured: electrical conductivity (EC), $\mathrm{pH}$, dissolved oxygen (DO), water oxygenation, hardness, and the concentrations of: $\mathrm{NH}_{4}{ }^{+}, \mathrm{NO}_{2}{ }^{-}, \mathrm{NO}_{3}{ }^{-}, \mathrm{PO}_{4}{ }^{3-}, \mathrm{Cl}^{-}, \mathrm{SO}_{4}{ }^{2-}$, $\mathrm{S}^{2-}, \mathrm{Mn}^{2+}, \mathrm{Fe}^{2+/ 3+}$, and $\mathrm{SiO}_{2}$. For the 5-days biological oxygen demand $\left(\mathrm{BOD}_{5}\right)$ determination, water samples in glass bottles were transported to a laboratory. The bottles were incubated in the dark for 5 days at $20^{\circ} \mathrm{C}$. The $\mathrm{BOD}_{5}$ 
Table 1 Morphological characteristics of the sampling sites and aquatic plants

\begin{tabular}{|c|c|c|c|c|c|c|c|c|}
\hline Site & Depth (m) & Macrophytes & Light intensity & $\begin{array}{l}\text { Bottom substrate } \\
\text { st/gr/sa/cl/bs (\%) }\end{array}$ & $\begin{array}{l}\text { Organic } \\
\text { matter ma/ } \\
\text { de }\end{array}$ & Fine sediments & $\begin{array}{l}\text { Small } \\
\text { woody } \\
\text { debris }\end{array}$ & $\begin{array}{l}\text { Aquatic and marsh vegetation } \\
\text { (most abundant taxa) }\end{array}$ \\
\hline 1 & $0.5-0.8$ & $* * * *$ & ++++ & $5 / 5 / 10 / 60 / 20$ & $* * * / * *$ & $*$ & $* * *$ & $\begin{array}{l}\text { Phragmites australis, Schoeno- } \\
\text { plectus lacustris, Hydrocharis } \\
\text { morsus-ranae }\end{array}$ \\
\hline 2 & $4-6$ & $* * *$ & +++ & $5 / 10 / 10 / 45 / 30$ & $* * * / * *$ & $* *$ & $* * *$ & $\begin{array}{l}\text { Potamogeton crispus, } \text { P. natans, } \\
\text { Stuckenia pectinata, Elodea } \\
\text { canadiensis }^{\mathrm{a}} \text {, Ceratophyllum } \\
\text { demersum }\end{array}$ \\
\hline 3 & $10-12$ & $* *$ & ++ & $10 / 20 / 20 / 5 / 45$ & $* / * *$ & $* * *$ & $* *$ & $\begin{array}{l}\text { C. demersum, Potamogeton per- } \\
\text { foliatus, Chara sp., Fontinalis } \\
\text { antipyretica }\end{array}$ \\
\hline 4 & $18-20$ & - & + & $10 / 20 / 20 / 5 / 45$ & $-/ * * *$ & $* * * *$ & $* *$ & Benthic algae \\
\hline
\end{tabular}

st stones, $g r$ gravel, sa sand, $c l$ clay, $b s$ broken shells (Dreissena sp.), ma dead macrophytes, de detritus

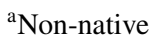

5-point scale: ${ }^{-}$lack; $* * * *$ very numerous; light visibility 5 -point scale: ${ }^{+}$low, ${ }^{++++}$high

was calculated after the 5 day period, the final DO content was determined, and the difference between the final DO reading and the initial DO reading was calculated.

Macroinvertebrates were sampled using a benthic sampler (area $0.05 \mathrm{~m}^{2}, 0.33 \mathrm{~mm}$ mesh size). Ten quantitative benthic samples were collected at each site and sampling period from all habitat types present on the site. In total, 120 samples were collected (10 samples $\times 4$ sites $\times 3$ seasons). The collected animals and residues were fixed with $4 \%$ formaldehyde and then in $75 \%$ ethanol. For taxa identification, a stereoscopic microscope (SMZ1500, Nikon Instruments Europe B.V., Amsterdam, The Netherlands) and corresponding keys (Bauernfeind and Lechthaler 2014; Dobson 2013; Elliott and Humpesch 2010; Nilsson 1996, 1997; Tachet et al. 2002; Wallace 1981) were used. Specimens of macroinvertebrate samples were identified to the lowest possible taxonomic level (mostly species/genus). Invertebrates were counted, their length was measured, and they were divided into size classes. The taxa were weighed on an electronic balance with an accuracy of approximately $0.0001 \mathrm{~g}$. Animals used for weighing were preserved in formalin. According to Leuven et al. (1985) and Benke et al. (1999), formalin-preserved animals provide calculated mass estimates similar to those obtained using fresh animals. This provided the basis for calculating the biomass of the taxa at the sites. The allocation of each taxon to the functional feeding group (FFG) was based on the mouthpart morphology and FFG allocations from the literature (e.g. Buczyńska 2019; Merritt and Cummins 1996; Moog 2002). 'Demon shrimp' (Dikerogammarus heamobaphes (Eichwald)) was classified into the omnivores group (Bacela-Spychalska and van der Velde 2013).

\section{Data Analysis}

The numbers and biomass of the invertebrates were calculated per bottom surface area (number of individuals per $\mathrm{m}^{2}$, and $\mathrm{mg} \mathrm{m}^{-2}$, respectively). Statistical data analyses were performed using STATISTICA 12 (TIBCO Software Inc., Palo Alto, CA, USA), and all multivariate analyses were performed using PRIMER v7 (Anderson et al. 2008). Differences between the mean density (data was squareroot transformed) of the most abundant taxa at individual seasons, and then at sites, were analysed using a nonparametric one-way ANOVAs (Kruskal-Wallis tests) and post hoc tests for Kruskal-Wallis ANOVA (Dunn's test). The densities of Trichoptera larvae at sites 1 and 2 were compared using a Mann-Whitney U test (Zar 2010).

To illustrate the spatial variability in benthic community dissimilarities, a principal coordinate analysis (PCO) plot was generated. PCO uses a symmetric resemblance matrix (Legendre and Legendre 1998) that in this instance was based on Bray-Curtis distances, using densities of invertebrate taxa (list of taxa according to Table S1; with species of caddisflies and mayflies grouped into two taxa: Trichoptera and Ephemeroptera, respectively). Two-way permutational multivariate analysis of variance (PERMANOVA) (Anderson et al. 2008) with Site and Season as fixed factors was used to analyse the variation in community structure. The data was square-root transformed. PERMANOVA was performed with pairwise comparisons (Bonferroni post hoc test) to test if there were significant differences in macroinvertebrate assemblages among sites and among seasons. Similarity percentages procedure (SIMPER) was used to identify which macroinvertebrate 
taxa were most likely responsible for dissimilarities between the studied sites detected by PERMANOVA.

Pairwise dissimilarities were calculated among all sites, and the taxa most influencing total dissimilarities between compared sites were identified. The list of taxa was truncated at $80.00 \%$, and therefore restricted to the higher-contributing taxa. The best discriminator taxa were designated by dividing the average dissimilarity contribution (AvContr) by the standard deviation (SD) of this contribution, which gives a measure of how consistently the taxon contributes to the dissimilarity (Clarke 1993). A good discriminator taxon is one which contributes relatively consistently to that distinction for all site pairs, i.e. with a higher value of the AvContr/SD ratio. The percentage share of each taxon in the Bray-Curtis similarity within the samples from a given site was also determined, designating taxa typical of the site. The more abundant a taxon is at the site, the more it contributes to similarity within the site. The species typifying the site was found in samples from a given site in constant abundance and the ratio of its contribution in the similarity (Sim) within the site to standard deviation (Sim/SD) was high. A taxon typifies a given site if it is found in constant abundance, and therefore the SD of its share is low and the Sim/SD ratio is high (Clarke and Gorley 2015).

\section{Diversity Indices}

The assessment of invertebrate diversity involved the use of diversity indices (calculated for the mean density) (Clarke et al. 2014; Krebs 2001; Magurran 2004). The Shannon diversity index $\left(\mathrm{H}^{\prime}\right)$ is used to compare diversity between habitats and was calculated using: $\mathrm{H}^{\prime}=-\left(\sum \mathrm{P}_{\mathrm{i}} \ln \mathrm{P}_{\mathrm{i}}\right)$, where $\mathrm{H}^{\prime}$ is the diversity index; $\mathrm{P}_{\mathrm{i}}$ is the proportion of each taxon in the sample; and $\ln \mathrm{P}_{\mathrm{i}}=$ the natural logarithm of this proportion. The Pielou's evenness index $(\mathrm{J})$ is the most frequently used measure of evenness and it was calculated via the following formula: $\mathrm{J}=\mathrm{H}^{\prime} / \ln (\mathrm{S})$, where $\mathrm{H}^{\prime}$ is the Shannon index and $\mathrm{S}$ is the number of taxa observed. Invertebrates identified to the lowest possible taxonomic level (mayflies, caddisflies, damselflies, crustaceans, snails, and mussels: a species level; chironomids: subfamily or tribe level; oligochaetes: a subclass Oligochaeta) were used for the calculations of indices. It allows the comparison of the diversity of macroinvertebrate assemblages among sites and/or seasons. Such information is of high value for freshwater ecologists (Jones 2008). The assessment of the ecological status of the pit lake was supported by the diversity index $d$, for which the categories of ecological status were assigned in the Water Framework Directive (WFD) (European Commission 2000). The diversity index $d$ was calculated via the following formula: $d=S / \log N$, where $d$ is the diversity index $d$ (modified after Margalef); $\mathrm{S}$ is the number of occurring families, and $\mathrm{N}$ is the total number of individuals per $1 \mathrm{~m}^{2}$ (AQEM
Consortium 2002; Magurran 2004). Differences between the mean indices values at four sites (using log-transformed data), were analysed using one-way ANOVAs and Tukey's post hoc tests.

\section{Results}

The Machów pit lake has clear water and light reaches a great depth, allowing submerged plants to occur over a considerable part of the lake bottom. At the studied lake, the shallow sites were generally warmer (Fig. 2) and had a dominant clay substrate, and the densest concentration of aquatic vegetation. Site 1 was overgrown by emergent vegetation, particularly the common reed (Phragmites australis (Cav.) Trin. ex Steud.) and common club rush (Schoenoplectus lacustris (L.) Palla). More than half of the bottom surface (benthic zone) was covered by clay, and detritus in the form of dead macrophytes was abundant. The vascular plants at site 2 were represented by the curly-leaf pondweed (Potamogeton crispus L.) and floating-leaved pondweed (Potamogeton natans L.) as well as the hornwort (Ceratophyllum demersum L.), and non-native American waterweed (Elodea canadensis Michaux). Abundant light could penetrate to the depth of this site. In addition to clay, the bottom was covered by considerable amounts of empty and broken shells (Dreissena sp.) as well as gravel and stones. Deep sites were cooler and showed less evident plant growth, and the substrate was frequently composed of broken shells and fine sediments. At depths of 10-12 m, perfoliate pondweed (Potamogeton perfoliatus L.) was present and the green algae Chara sp. as well as benthic algae were abundant. Visibility at this site was good, and the level of light penetration was high. At the deepest site, chlorophytes were observed, and small-particle sediments were the most abundant substrate (Table 1).

The mean water temperature was the highest at site 1 $\left(13.1^{\circ} \mathrm{C}\right)$ and decreased with depth $\left(5.3{ }^{\circ} \mathrm{C}\right.$ at site 4$)$. Water temperatures in spring and autumn were similar at all sites, and ranged from 4.0 to $6.7^{\circ} \mathrm{C}$. In summer, water temperature at site 1 was $19.9^{\circ} \mathrm{C}$, and at the other sites ranged from 7.0 to $8.5^{\circ} \mathrm{C}$. The EC in each research period was $\approx 1000 \mu \mathrm{S}$ $\mathrm{cm}^{-1}$, and the concentration of chlorides exceeded $150 \mathrm{mg}$ $\mathrm{L}^{-1}$. The DO concentration was high (9-12 $\left.\mathrm{mg} \mathrm{L}^{-1}\right)$. The lowest water $\mathrm{pH}(\approx 7.0)$ was recorded in Spring. The concentration of nitrate was $\approx 1 \mathrm{mg} \mathrm{L}^{-1}$, nitrite was $<0.1 \mathrm{mg} \mathrm{L}^{-1}$, ammonium was $<0.01 \mathrm{mg} \mathrm{L}^{-1}$, phosphate was $\approx 0.05 \mathrm{mg}$ $\mathrm{L}^{-1}$, and sulphate ions was $\approx 200 \mathrm{mg} \mathrm{L}^{-1}$. Sulphides were always detectable; the highest value was recorded in summer at site $4\left(0.04 \mathrm{mg} \mathrm{L}^{-1}\right)$. In the littoral zone (site 1$)$, the sulphide concentrations ranged from 0.001 to $0.02 \mathrm{mg} \mathrm{L}^{-1}$ (Fig. 2).

Insect larvae (excluding dipterans) were most abundant at the shallowest site (mean density: 357.1 ind. $\mathrm{m}^{-2}$ ). Mayflies 

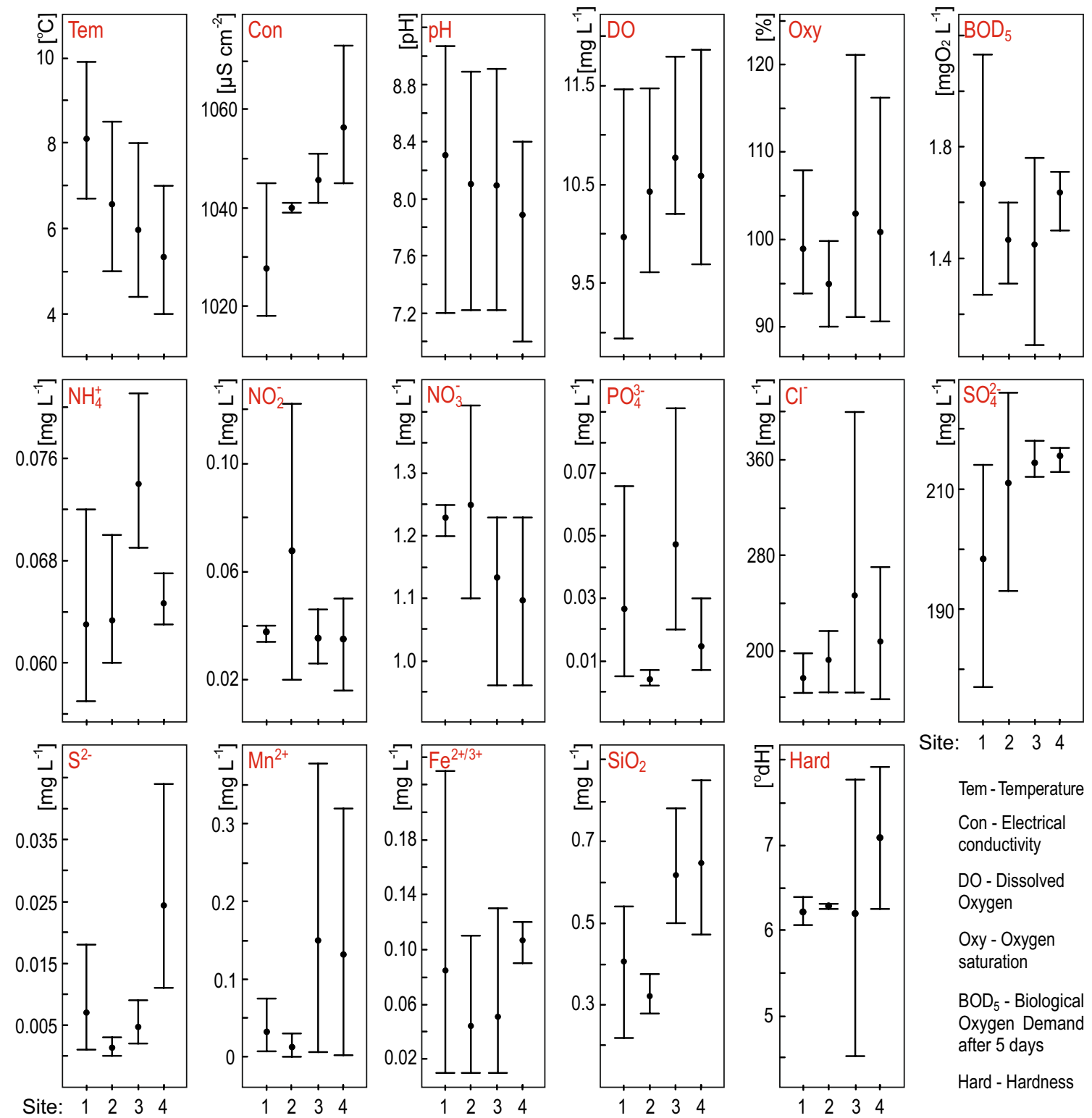

Site: 12234

\section{Tem - Temperature \\ Con - Electrical conductivity \\ DO - Dissolved \\ Oxygen \\ Oxy - Oxygen saturation \\ $\mathrm{BOD}_{5}$ - Biological Oxygen Demand after 5 days \\ Hard - Hardness}

Fig. 2 Summary of the physico-chemical characteristics of the water in the Machów pit lake. Plots depict the following: lower and upper limits of whiskers show range of parameters values, central filled circle is a mean value

were represented by the family Caenidae, caddisflies were represented by families Leptoceridae and Hydroptilidae, and dragonflies were only represented by the blue-tailed damselfly (Ischnura elegans Vander Linden) (Coenagrionidae). Among the flies, scarce larvae of Ceratopogonidae were recorded at sites 1 and 2. Chironomidae were abundant at all of the sites, whereas the genus Chironomus sp. was only found at sites 3 and 4 . The Caspian mud shrimp (Chelicorophium curvispinum (G.O. Sars)) was only present at the two shallower sites, while the other representative of amphipod crustaceans, the "demon shrimp", occurred at a depth of up to $20 \mathrm{~m}$. Oligochaeta were the most abundant at site 4 , and the density of the zebra mussel (Dreissena polymorpha (Pallas)) increased with depth (Table S1). Zebra mussels were dominant in the invertebrate biomass at all sites in all seasons (Fig. 3). Moreover, at sites 1 and 2, the sponge (Spongilla lacustris (L.)), was present. Collectors dominated in numbers at almost all sites. Shredders reached $0.2 \%$ and $0.5 \%$ of relative abundance, respectively, at site 1 and 2. Predators occurred in the highest mean density (248 ind. $\mathrm{m}^{-2}$ ) at site 1 (Fig. S1). The lowest Shannon diversity $\left(\mathrm{H}^{\prime}\right)$ index values were determined at the deepest part of the pit lake (site 4), while the highest values were observed at depths of $0.5-0.8 \mathrm{~m}$ (site 1). The highest Pielou's evenness index $(\mathrm{J})$ value was also calculated at the shallowest site. The highest diversity d index values were determined at the 
Fig. 3 Percentages of benthic macroinvertebrate main taxa (left panel), and the most abundant taxa (right panel) sampled from the Machów pit lake; (S) spring; (U) summer; (A) autumn; (i) zebra mussels; (ii) amphipods; (iii) oligochaetas; (iv) insects (excluding dipterans); (v) chironomids; arrow indicates increase in water depth

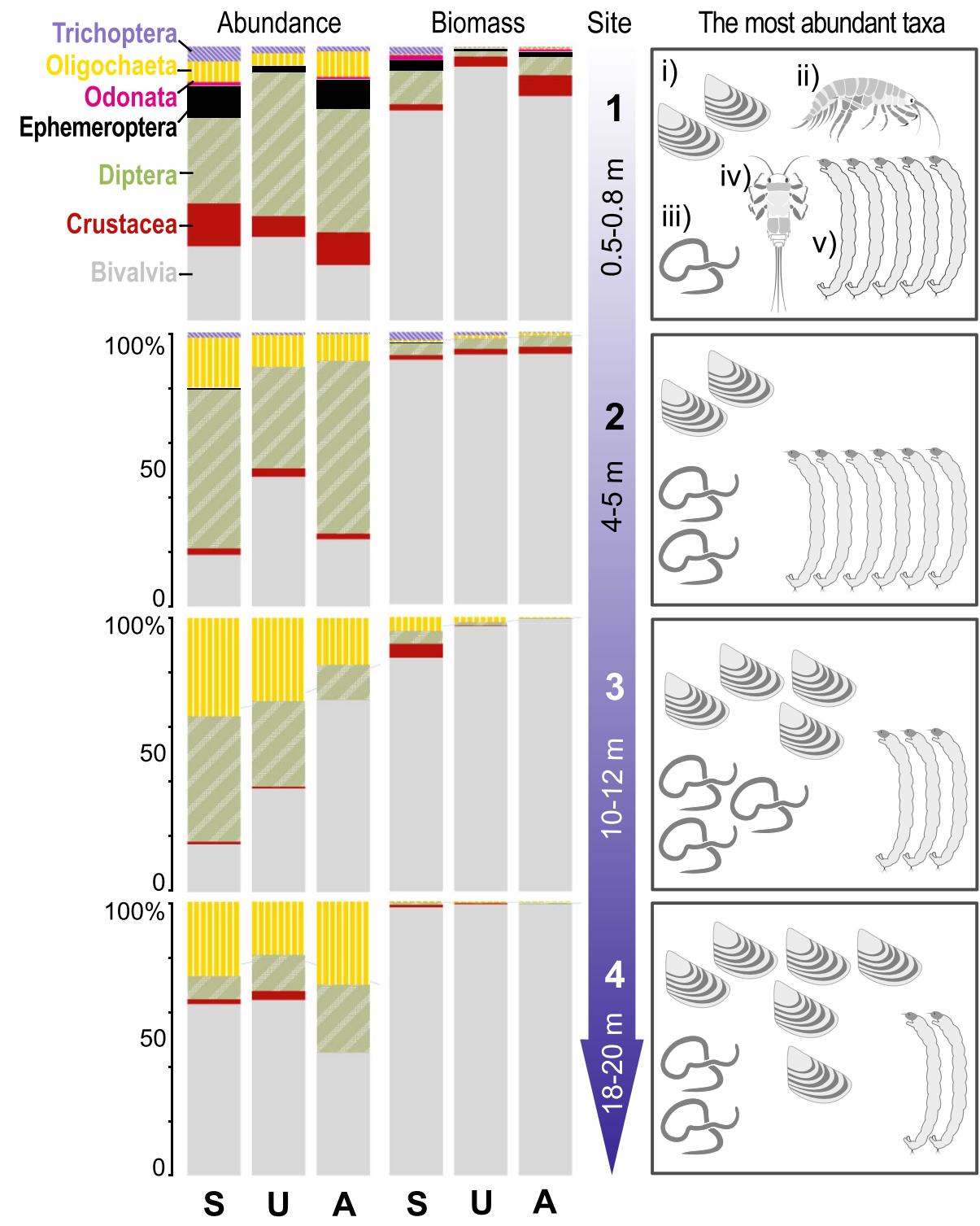

shallowest part of the pit lake (site 1); in Spring, it was 2.5 (Fig. S2), indicating moderate ecological status (AQEM Consortium 2002). At other sites, the index values were in the 1.0-2.0 range (Fig. S2), indicating poor ecological status (AQEM Consortium 2002). The mean values of diversity indices differed significantly among sites (ANOVA, $\mathrm{P}<0.01$ ) (Fig. S2).

There were significant differences in Chironomini, Tanypodinae, and Diptera larvae, as well as Oligochaeta, Dikerogammarus, and Dreissena densities relative to site ( $\mathrm{P}<0.001)$. Chironomini, Tanytarsini, Tanypodinae, Diptera, Trichoptera, Dikerogammarus, and Oligochaeta densities varied seasonally (Fig. 4). The PCO analysis showed that the horizontal axes explain separation with $49.98 \%$ total variation. The vertical axes explained separation with $22.01 \%$ total variation. With the PCO1 axis, the Tanytarsini had a positive relationship, while the abundance of
Oligochaeta and Dreissena had negative relationships with this axis. The $95 \%$ ellipsoids in the ordination plot showed substantial assemblage overlap between sites 3 and 4, but notable differences between the deeper depths assemblages (i.e. sites 3 and 4) and benthic assemblages occupying shallower depths (i.e. sites 1 and 2) (Fig. 5). In the two-way PERMANOVA, both main effects were significant, and there was significant interaction of site and season. This analysis also showed (MS values), that the effect of site was much greater than the effect of season on assemblages (Table 2). Further analysis using post hoc pair-wise tests indicated significant differences between all pairs, for both "site" $(P=0.001)$, and "season" $(P=0.001)$ factors.

When the list of taxa was truncated at $80 \%$ of cumulative contribution, only five taxa accounted for the dissimilarity between sites. The average Bray-Curtis dissimilarity between all samples in each pair of sites ranged from $36.3 \%$ 
Fig. 4 Box-and-whisker plots summarizing main taxa densities for each season and site; (S) spring, (U) summer, (A) autumn; (1-4) sites. Boxplots depict the following: lower and upper limits of whiskers show range of density values, lower and upper boundaries of box represent 25 th and 75 th percentiles, horizontal line within box is median value; $* * * \mathrm{P}<0.001$, $* * \mathrm{P}<0.01, * \mathrm{P} \leq 0.05, N S$ differences not significant; underlined groups did not differ significantly
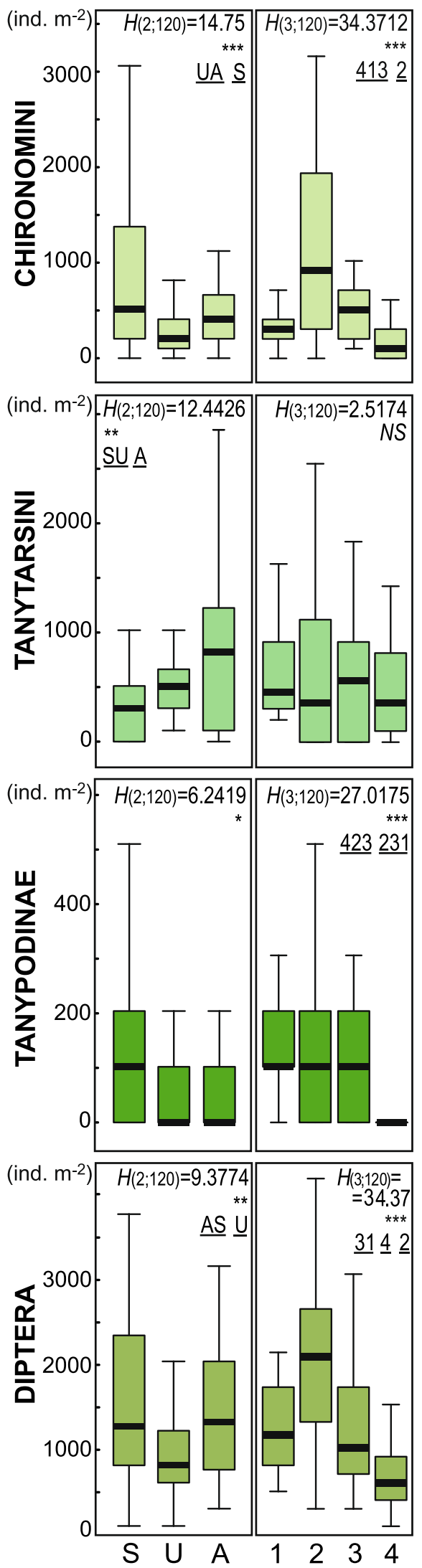

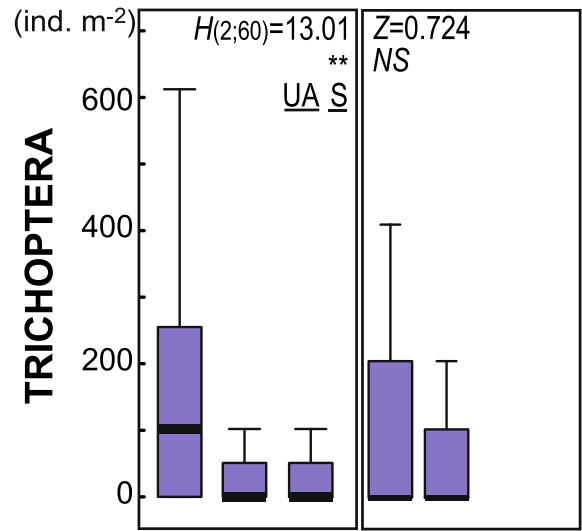

(ind. $\left.\mathrm{m}^{-2}\right) \quad H(2 ; 120)=7.8316 \quad H(3 ; 120)=17.8233$
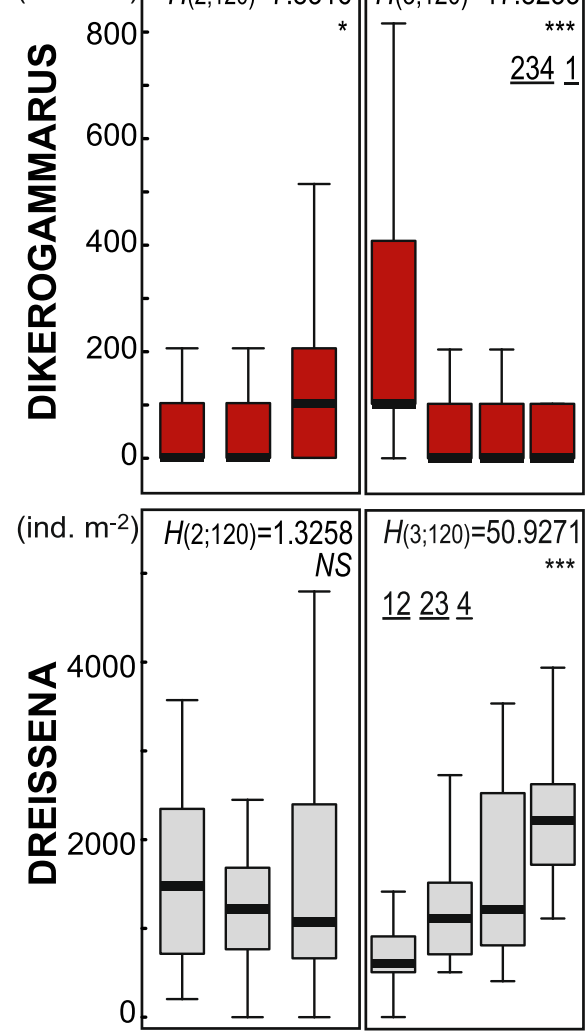

(ind. $\left.\mathrm{m}^{-2}\right) \quad H(2 ; 120)=16.2343 \quad H(3 ; 120)=59.2274$

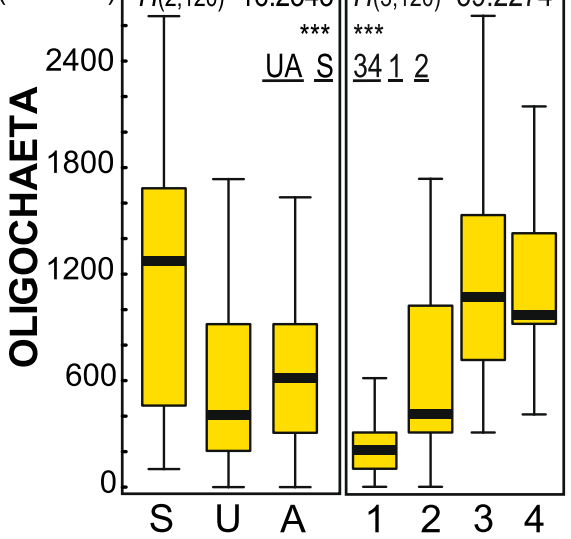




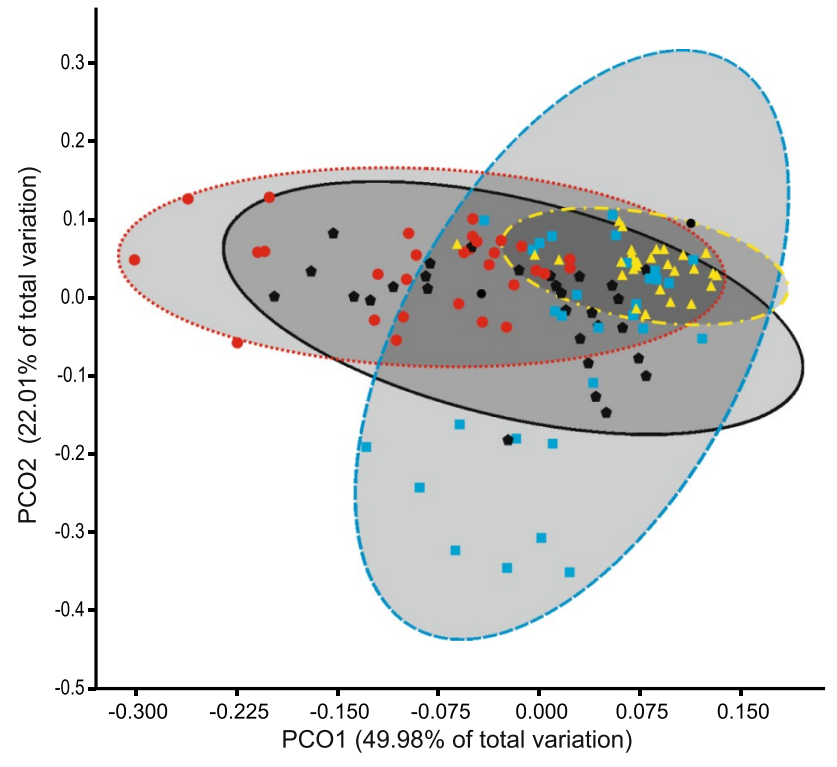

Fig. 5 Principal coordinates analysis (PCO) ordination plot based on Bray-Curtis distances of benthic assemblage abundance data. Each point represented the centroid of the observed dissimilarity among sites; triangles and dash-dotted ellipsoid, site 1; squares and dashed ellipsoid, site 2; pentagons and solid ellipsoid, site 3; circles and dotted ellipsoid, site 4

Table 2 Two-way PERMANOVA results based on Bray-Curtis distances of abundance data for assemblages of invertebrates in Machów pit lake in three seasons and at four sites

\begin{tabular}{lrrrrl}
\hline Source & d.f. & \multicolumn{1}{l}{ SS } & \multicolumn{1}{l}{ MS } & Pseudo-F & $P$ \\
\hline Site & 3 & 45,639 & $15,213.0$ & 30.439 & 0.0001 \\
Season & 2 & 15,002 & 7500.9 & 15.008 & 0.0001 \\
Site x season & 6 & 31,165 & 5194.1 & 10.393 & 0.0001 \\
Residual & 108 & 53,977 & 499.8 & & \\
Total & 119 & 145,780 & & & \\
\hline
\end{tabular}

999_-permutations, Monte Carlo test

$S S$ sum of squares, $M S$ mean square

(site 2 vs. site 3 , and site 3 vs. site 4 ) to $53.4 \%$ for site 1 vs. site 2 (Table 3). The highest average dissimilarity (AvDis) in the comparison of site 1 and site 2 concerned Chironomini, Tanytarsini, and Dreissena. In all other pairwise comparisons, the highest AvDis was determined for Dreissena. The AvDis/SD ratio suggests that in three pairwise comparisons, Oligochaeta was a good discriminator of differences between site conditions (Table 3). The average Bray-Curtis similarity between all pair of samples at individual sites ranged from $54 \%$ at site 2 to almost $72 \%$ at station 4 (Table 4 ). The average Bray-Curtis similarity between all pairs of samples at individual sites mainly consisted of only two or three taxa: Dreissena Oligochaeta and Chironomini (sites 1-3). Only for site 1 , exceeding $80 \%$ of the share required the cumulative contributions of five taxa. The highest values of the AvDis/SD ratio at site 2 and 4 were determined by Dreissena; at site 1 by Chironomini and Tanytarsini larvae, and at site 3 by Oligochaeta (Table 4 ). These taxa can be described as typical of a given site.

\section{Discussion}

Before inundation, the lake was just a dry pit—an area that has not been previously occupied by aquatic communities. Aquatic invertebrate species could have been supplied to the surveyed pit lake from the river water used to fill the reservoir, or colonized from the air by insects laying eggs (Kirmer et al. 2008). The organisms found a newly developed pit lake that contained numerous free niches, and they likely acclimatised rapidly. It could be argued that their colonization of this lake was one of the stages of primary succession. At the same time, submerged vegetation also developed. Light reached a depth of at least $35 \mathrm{~m}$, allowing plants to grow over much of the lake bottom; however, the aquatic vegetation was densest at the shallowest sites.

Although rush and submerged vegetation developed in the Machów pit lake and provide potentially good habitat conditions for mayflies, caddisflies, and damselflies (Kornijów and Kairesalo 1994), these insects were scarce and were represented by only five families: Caenidae, Coenagrionidae, Ecnomidae, Hydroptilidae, and Leptoceridae. Mayflies, caddisflies, and damselflies inhabited the part of the lake largely exposed to solar radiation, overgrown by vascular vegetation at depths up to $5 \mathrm{~m}$. In natural freshwater lakes with a well-developed littoral zone, the abundance and species diversity of the fauna of Trichoptera, Ephemeroptera, Odonata, Hemiptera, and Coleoptera would be considerably higher (Merritt and Cummins 1996; Nilsson 1996, 1997).

In the studied pit lake, the only mayflies were Caenis spp., and among them, Caenis luctuosa (Burmeister) was dominant. This euryhaline species is found in both lentic and lotic habitats, although it prefers sand substrates with abundant detritus and is tolerant to mineralised and organically polluted waters (Belfiore 1983; Perán et al. 1999). Another species of Caenis horaria (L.) found in the Machów lake is also classified as a euryhaline-limnic taxon, and it tolerates a salinity of up to $10 \%$. It has been found with others in running waters in brackish marshes in Germany (Wolf et al. 2009). Caenis rivulorum Eaton is also resistant to slight increases in salinity (Williams and Williams 1998).

Caddisflies inhabiting the Machów lake also belonged to species more resistant to an increase in trophic status and water salinity. Oxyethira sp. is a successful and almost cosmopolitan genus (Marshall 1978). Bonada et al. (2004) reported that the Leptoceridae larvae tolerate high sulphate (up to $638 \mathrm{mg} \mathrm{L}^{-1}$ ) and chloride (up to $176 \mathrm{mg}$ 
Table 3 Taxa contributing of the dissimilarity between the invertebrate assemblages at four sites in the Machów pit lake (one-way SIMPER analysis)

\begin{tabular}{|c|c|c|c|c|c|c|c|}
\hline \multirow[t]{2}{*}{ Compared sites (AvDis) } & \multirow[t]{2}{*}{ Taxon } & \multicolumn{2}{|l|}{ AvAbu } & \multirow[t]{2}{*}{ AvDis } & \multirow[t]{2}{*}{ AvDis/SD } & \multirow[t]{2}{*}{ Con $(\%)$} & \multirow[t]{2}{*}{ CuCon $(\%)$} \\
\hline & & 1st site & 2nd site & & & & \\
\hline \multirow[t]{5}{*}{1 vs. $2(53.42 \%)$} & Chironomini & 346.94 & 1149.66 & 11.93 & 1.26 & 22.33 & 22.33 \\
\hline & Tanytarsini & 653.06 & 741.50 & 10.56 & 1.21 & 19.77 & 42.11 \\
\hline & Dreissena & 734.69 & 1244.90 & 10.30 & 1.26 & 19.28 & 61.39 \\
\hline & Oligochaeta & 221.09 & 717.69 & 7.21 & 1.16 & 13.49 & 74.88 \\
\hline & Dikerogammarus & 261.90 & 68.03 & 3.49 & 0.86 & 6.53 & 81.40 \\
\hline \multirow[t]{4}{*}{2 vs. $3(36.30 \%)$} & Dreissena & 1244.90 & 1605.44 & 11.32 & 1.21 & 25.05 & 25.05 \\
\hline & Chironomini & 1149.66 & 513.61 & 10.04 & 1.27 & 22.21 & 47.26 \\
\hline & Oligochaeta & 717.69 & 1153.06 & 9.78 & 1.36 & 21.65 & 68.91 \\
\hline & Tanytarsini & 741.50 & 578.23 & 9.73 & 1.20 & 21.52 & 90.43 \\
\hline \multirow[t]{3}{*}{3 vs. $4(36.30 \%)$} & Dreissena & 1605.44 & 2431.97 & 15.36 & 1.54 & 42.31 & 42.31 \\
\hline & Oligochaeta & 1153.06 & 1217.69 & 7.41 & 1.32 & 20.40 & 62.72 \\
\hline & Tanytarsini & 578.23 & 472.79 & 6.41 & 1.34 & 17.65 & 80.37 \\
\hline
\end{tabular}

Each taxon's contribution (Con) to the total dissimilarity between the groups is given as a percentage, and the cumulative contribution (CuCon) of each taxon is set to a cut-off point of $80.00 \%$. Column 6 gives the ratio of average dissimilarity (AvDis) divided by standard deviation (SD) $A v A b u$ average abundance; first site from the compared pair (1st site); second site from the compared pair (2nd site)

Table 4 Taxa contributing of the similarity in the invertebrate assemblages within each of the four sites in the Machów pit lake (one-way SIMPER analysis)

\begin{tabular}{llrrlrl}
\hline Site (AvSim) & Taxon & AvAbu & AvSim & AvSim/SD & Con $(\%)$ & CuCon $(\%)$ \\
\hline \multirow{2}{*}{$(55.86 \%)$} & Dreissena & 734.69 & 6.59 & 1.74 & 29.70 & 29.70 \\
& Tanytarsini & 653.06 & 15.46 & 2.23 & 27.68 & 57.38 \\
& Chironomini & 346.94 & 7.91 & 1.81 & 14.16 & 71.54 \\
& Oligochaeta & 221.09 & 4.38 & 1.11 & 7.84 & 79.38 \\
& Dikerogammarus & 261.90 & 3.44 & 0.75 & 6.16 & 85.54 \\
$2(54.50 \%)$ & Dreissena & 1244.90 & 23.26 & 2.54 & 42.67 & 42.67 \\
& Chironomini & 1149.66 & 13.32 & 1.25 & 24.44 & 67.11 \\
& Oligochaeta & 717.69 & 8.52 & 1.49 & 15.63 & 82.74 \\
& Dreissena & 1605.44 & 26.36 & 1.91 & 41.82 & 41.82 \\
& Oligochaeta & 1153.06 & 20.71 & 2.38 & 32.85 & 74.66 \\
& Chironomini & 513.61 & 7.86 & 1.65 & 12.48 & 87.14 \\
& Dreissena & 2431.97 & 42.94 & 4.74 & 60.02 & 60.02 \\
& Oligochaeta & 1217.69 & 20.45 & 3.43 & 28.59 & 88.61 \\
\hline
\end{tabular}

Each taxon's contribution (Con) to the total similarity within the site is given as a percentage, and the cumulative contribution (CuCon) of each taxon is set to a cut-off point of $80.00 \%$. Column 5 gives the ratio of average similarity (AvSim) divided by standard deviation (SD)

$A v A b u$ average abundance; number of considered samples $(n)$ for each site $=30$
$\mathrm{L}^{-1}$ ) concentrations, and the presence of caddisfly species from Leptoceridae (A. albifrons, M. longicornis, O. furva, $O$. ochracea) suggests the high resistance of these species to elevated concentrations of chlorides. The presence of another caddisfly, Ecnomus tenellus (Rambur), was surprising because it is considered to be a freshwater taxon that does not tolerate even low salinity (Wolf et al. 2009). According to our data, however, this species tolerated the presence of chlorides at a concentration of up to $\approx 220 \mathrm{mg}$ $\mathrm{L}^{-1}$ as well as sulphate (up to $0.007 \mathrm{mg} \mathrm{L}^{-1}$ ), and it has also been recorded in the smaller Piaseczno pit lake, which has a similar chloride concentration (Dumnicka and Galas 2006; Żurek 2006).

Moreover, in the Machów pit lake, the presence of sponges could be favourable for the littoral net-spinning $E$. tenellus. This species occurs in considerable numbers on sponges, and E. tenellus is an occasional sponge consumer (Gugel 2001). The order of dragonflies and damselflies in the Machów lake was represented by only one species, I. elegans, which is known as a common and eurytopic Zygoptera 
species and encountered in salinated water bodies (Boudot and Kalkman 2015). Coleoptera larvae, common in stagnant water bodies, e.g. Dytiscidae and Gyrinidae families, or hemipterans, were absent. Water reservoirs such as the Machów lake seem to be inappropriate for them, because the taxa were also not reported from the smaller Piaseczno sulphur pit lake (Dumnicka and Galas 2006). The only Hemiptera observed in the Machów lake were the scarce waterbugs, Gerris spp., visible on the water surface.

A New Zealand mud snail (Potamopyrgus antipodarum (J. E. Gray)) also appeared in the shallowest part of the reservoir; it is a common non-native species in fresh and brackish water ecosystems in Europe, and has become very abundant in some water systems (Davidson et al. 2008). In the studied lake, this species was rare, and occurred only in the shallowest zone. This might suggest that its introduction has occurred recently. The New Zealand mud snail is relatively tolerant of various pollutants, e.g. associated with agricultural development (Hall et al. 2001).

The deep-water (depth $\geq 4 \mathrm{~m}$ ) benthic macroinvertebrate community of the Machów lake was also dominated by a few invertebrate taxa, including chironomids, oligochaetes, and zebra mussels. Habitats at great depths are dominated by collector-gatherers inhabiting fine sediments, which include Chironomidae and Oligochaeta (Grzybkowska et al. 2012; Heling et al. 2018; Tachet et al. 2002). Interestingly, the amount of stones and coarse gravel substrate in the surveyed pit lake was small, and increased with depth. This might be one of the reasons for the increased density of the mussels with depth. Zebra mussels attach to any stable substrate: rocks, stones, or even artificial surfaces (Ricciardi et al. 1997). Overall, the mean densities in the Machów lake (735-2694 ind. $\mathrm{m}^{-2}$ ) were close to those from other European lakes (Alix et al. 2016; Burlakova et al. 2000). The presence of Dreissena sp. creates a favorable habitat for Chironomidae larvae, and their high abundance was recorded in the substrate developed by the zebra mussels (Ricciardi et al. 1997). Fine mineral particles and detritus accumulate between Dreissena sp. shells, thereby providing a suitable habitat for species inhabiting sediments (Karatayev et al. 2002). This non-native species was probably introduced to the Machów pit lake from the Vistula River, where it is quite a common species of Ponto-Caspian origin (Bij de Vaate et al. 2002).

In addition to the zebra mussel, the non-native Caspian mud shrimp, and "demon shrimp" were probably also transported to the Machów lake from the Vistula River (Grabowski et al. 2007). These species represent part of the so-called "Caspian complex", i.e. the autochthonous faunistic complex of the Ponto-Caspian basin. In the Machów lake the "demon shrimp" occupied habitats at any depth and were even present at a depth of $20 \mathrm{~m}$. These organisms also benefit from the presence of mussels. Empty mussel shells and living mussels increase the complexity of the substrate and provide hiding places (Kobak et al. 2009, 2014). In the shallower part of the lake, the "demon shrimp" might be feeding on C. curvispinum, whereas in the deeper areas, it could be Chironomidae larvae. "Demon shrimp" can also eat detritus and plant material (Bacela-Spychalska and van der Velde 2013).

In the Machów mine area, reasonable efforts were made to neutralise post-refining wastes, isolate the pit from groundwater containing $\mathrm{H}_{2} \mathrm{~S}$ (Felter et al. 2017), and reclaim the post-mining area. The problems of elevated chloride concentrations and introduction of non-native species were marginalised. The current composition of the invertebrate assemblage was probably primarily determined by the water used to fill the reservoir. According to Hammer (1986), the salinity of the Machów pit lake $\left(>1 \mathrm{~g} \mathrm{~L}^{-1}\right)$, i.e. falls within the lower range of subsaline. This suggests conditions very different from those of a natural freshwater lake. On the other hand, the lack of natural deep lakes in the studied area provides no basis for the conclusion that they should 'naturally' be freshwater. The reason for the elevated salinity in pit lakes (compared to natural freshwater lakes) is very often the oxidation of sulphides and the resulting acidification, which in turn causes mineral dissolution. In some cases, naturally occurring accumulations of salt minerals (evaporites) also play a role. This applies to sulphur deposits exploited in open cast mines in the Carpathian Foredeep (Felter et al. 2017; Geller et al. 2013). The sulphur deposits formed in geological series of evaporites including gypsum/anhydrite and halite and other chloride containing minerals. Due to this, the Piaseczno pit lake $(\approx 2.5 \mathrm{~km}$ from the Machów lake) has sulphate and chloride concentrations considerably higher than those of the Machów lake (Żurek 2006). Therefore, natural groundwater in the region may be subsaline or saline due to the geological strata hosting the sulphur deposits. It cannot be excluded that, due to the geological aspects of the terrain, a natural lake cutting into the ground as deep as the Machów pit lake, would also be characterized by subsaline water. The natural groundwater in the Machow region is probably subsaline or saline in the geological strata hosting the sulphur deposits (Geller et al. 2013). No natural lakes occur in the area, however.

To sum up, two factors: abiotic, salinated water and biotic introduction of non-native species, could have affected the developing biocoenosis of the water body. All non-native species occurring in the Machów pit lake are resistant to the salinity of the water (Davidson et al. 2008; Grabowski et al. 2009; Mordukhay-Boltovskoy 1964). Compared with mussels or crustaceans, aquatic insects are almost exclusively associated with freshwater. Stoneflies, mayflies, caddisflies, dragonflies, and damselflies, hemipterans, or coleopterans do not have many representatives in brackish waters, and they have no representatives in 
marine waters (Nilsson 1996, 1997). Therefore, there were only a few of their representatives in the surveyed pit lake.

It is difficult to determine whether a freshwater lake (with a salinity $<0.5 \mathrm{~g} \mathrm{~L}^{-1}$; Hammer 1986) could be established at the Machów site. Many strongly protected, naturally saline inland water bodies exist worldwide. They are valuable ecosystems (Hammer 1986; Jellison et al. 2008). In the Machów pit lake, elevated salinity was an abiotic factor that gave the non-native species an edge, as autochthonous species, with some exceptions, were not able to survive in the subsaline system. Abiotic factors undoubtedly affect all biotic interactions and can promote pioneer colonisers (Krebs 2001). In the studied pit lake, one of the pioneer colonisers was probably the zebra mussel because the planktonic veliger larvae of this species can be easily transported with water (Karatayev et al. 2002). Navigation has been considered the primary vector of dispersion. Little importance has been given to alternative natural (waterfowl) and other human vectors (Banha et al. 2016). Recreational boats circulate large amounts of raw water when in use and if not drained, can transport mussel larvae. If they are not transported with water, however, veligers experience very high mortality rates (Dalton and Cottrell 2013). Natural vectors, such as ducks, can contribute to the transport of zebra mussel larvae, but only at a local scale (Banha et al. 2016). The monopolisation of favourable habitats in the Machów pit lake by this species by preemption seems highly probable. As a result, a specific low-diversity assemblage developed in the surveyed pit lake, with a few autochthonic taxa and non-native species constituting a part of the 'Caspian complex' (Fig. 6).
Achieving effective reclamation of an open cast mine requires evaluation of the efficacy of the design of the pit lake ecosystems (Vandenberg and McCullough 2017). Our results confirm their recommendation that at the pit lake design stage, proper decisions about the water source for filling the pit are particularly important. Moreover, possible ways to deter introduction of non-native species should be taken into account. Otherwise, a newly created artificial lake may became a reservoir of non-native species. From the early stages of open cast mine reclamation, all efforts should be made for the biological characteristics of the pit lakes to be similar to the natural water bodies typical of a given area. Planning, designing, and developing efficient reclamation of open cast mines for beneficial uses is possible by incorporating ecological concepts and ecosystem design.

Because of the lack of natural lakes in the vicinity of the Machów pit lake, the use of recultivation methods to reduce the elevated chloride, sulphate, or sulphide concentrations and improve water quality cannot be justified. Measures that should be planned in the near future include commencement of continuous monitoring of water quality, particularly in the near-bottom layers of the lake, to protect the lake from the effect of groundwater containing $\mathrm{H}_{2} \mathrm{~S}$, which at high concentrations is a toxic gas. Continuous monitoring of physicochemical water properties seems essential. Although the isolation layer on the bottom will ideally prevent access of the $\mathrm{H}_{2} \mathrm{~S}$, monitoring seems prudent, especially since the Machów lake has become a very popular recreational area for sunbathing, sailing, and diving over the last 3 years.

Research on the physicochemical groundwater properties has been conducted in the pit lake area since 1997.

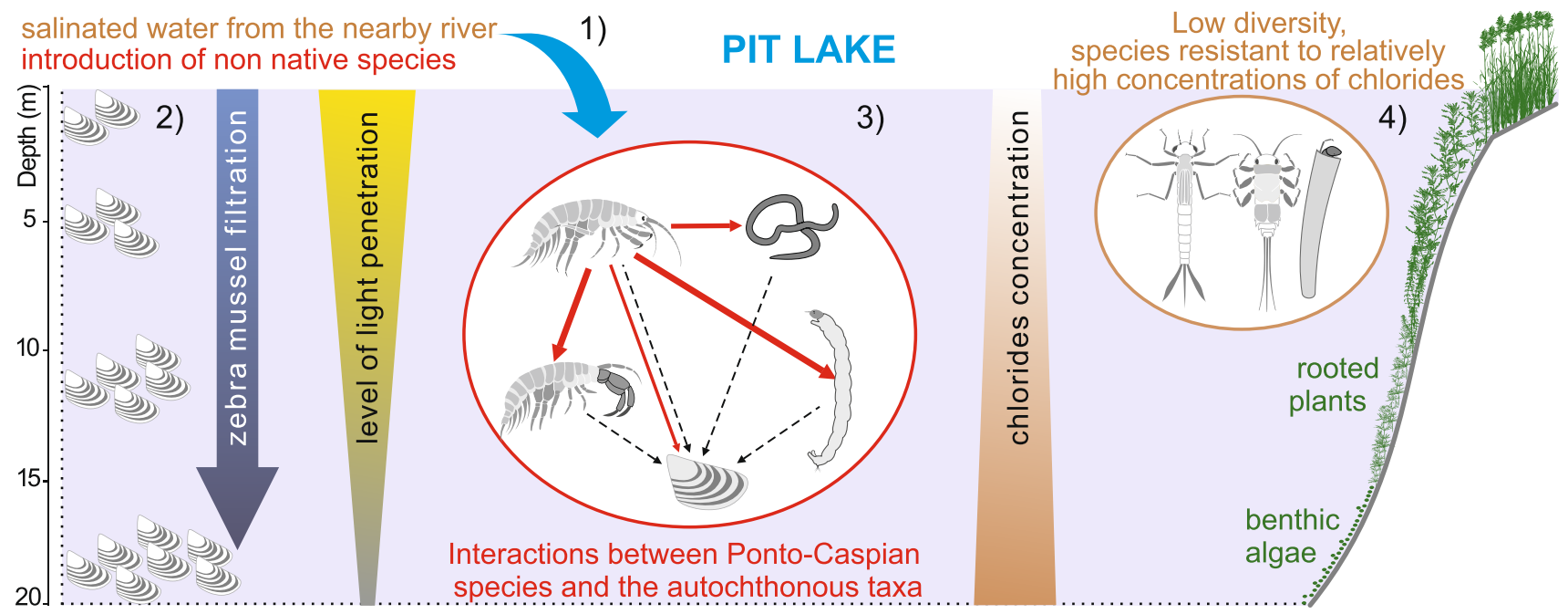

Fig. 6 A conceptual diagram depicting main factors affecting the invertebrate assemblage in the Machów pit lake; (1) Filling of the open mine pit with water from the Vistula River, was probably associated with the introduction of alien species of Ponto-Caspian origin; (2) Zebra mussel density increased with depth; (3) Possible interac- tions between zebra mussel and other Ponto-Caspian species as well as the autochthonous taxa; (4) Filling the pit with water from the Vistula River probably led to the elevated chloride concentrations, which keeps mayfly, caddisfly, and damselfly diversity low 
Hydrogeological research showed that Neogene groundwater in the area are strongly mineralised sulphuric waters. Due to this, the area has the potential for uptake of mineralised sulphuric waters occurring in Neogene deposits and their use in balneotherapy (Felter et al. 2017), which may broaden the possible use of the reclaimed area in the future.

Acknowledgements The authors especially thank K. Makowiecki, head of the "Aquarius" diving school, for providing invaluable help in water and benthic sampling; D. Kiełk for taking underwater pictures; and members of the Machów Diving Base for their organizational help. The authors also thank the anonymous reviewers for their helpful and constructive comments that greatly contributed to improving the final version of the paper. Funding of this work was provided by the BR/ KBŚ/1UPB/2013 funds.

Open Access This article is distributed under the terms of the Creative Commons Attribution 4.0 International License (http://creativeco mmons.org/licenses/by/4.0/), which permits unrestricted use, distribution, and reproduction in any medium, provided you give appropriate credit to the original author(s) and the source, provide a link to the Creative Commons license, and indicate if changes were made.

\section{References}

Alix M, Knight RJ, Ormerod SJ (2016) Rapid colonisation of a newly formed lake by zebra mussels and factors affecting juvenile settlement. Manag Biol Invasion 7:405-418

Anderson MJ, Gorley RN, Clarke KR (2008) PERMANOVA + for PRIMER: guide to software and statistical methods. PRIMER-E, Plymouth

AQEM Consortium (2002) Manual for the application of the AQEM system. a comprehensive method to assess European streams using benthic macroinvertebrates, developed for the purpose of the Water Framework Directive, version 1.0 Feb 2002. www.aqem. de; www.life-inhabit.it/cnr-irsa-activities/it/download/.../15-aqem

Bacela-Spychalska K, van der Velde G (2013) There is more than one 'killer shrimp', trophic positions and predatory abilities of invasive amphipods of Ponto-Caspian origin. Freshw Biol 58:730-741

Bain MB, Finn JT, Booke HE (1985) Quantifying stream substrate for habitat analysis studies. N Am J Fish Manage 5(3B):499-500

Banha F, Gimeno I, Lanao M, Touya V, Durán C, Peribáñez MA, Anastácio PM (2016) The role of waterfowl and fishing gear on zebra mussel larvae dispersal. Biol Invasions 18:115-125

Barker SL, Kim JP, Craw D, Frew RD, Hunter KA (2004) Processes affecting the chemical composition of Blue Lake, an alluvial goldmine pit lake in New Zealand. Mar Freshw Res 55:201-211

Bauernfeind E, Lechthaler W (2014) Ephemeroptera-key to larvae from Central Europe. DVD Edn. Eutaxa, Vienna

Belfiore C (1983) Guides for the recognition of animal species in Italian inland waters, 24 Mayflies (Ephemeroptera) Consiglio Nazionale delle Ricerche. Rome (in Italian)

Benke AC, Huryn AD, Smock LA, Wallace JB (1999) Length-mass relationships for freshwater macroinvertebrates in North America with particular reference to the southeastern United States. J N Am Benthol Soc 18:308-343

Bij de Vaate A, Jazdzewski K, Ketelaars HAM, Gollasch S, van der Velde G (2002) Geographical patterns in range extension of Ponto-Caspian macroinvertebrate species in Europe. Can J Fish Aquat Sci 59:1159-1174
Bonada N, Zamora-Muñoz C, Rieradevalla M, Prat N (2004) Ecological profiles of caddisfly larvae in Mediterranean streams, implications for bioassessment methods. Environ Pollut 132:509-521

Boudot JP, Kalkman VJ (2015) Atlas of the European dragonflies and damselflies. KNNV Uitgeverij, Boulevard

Buczyńska E (2019) Storage reservoirs beyond a lake district as secondary habitats for caddisflies (Insecta: Trichoptera) in an area of karst origin (SE Poland). Knowl Manag Aquat Ecosyst 420:4

Burlakova LE, Karatayev AY, Padilla DK (2000) The impact of Dreissena polymorpha (Pallas) invasion on unionids bivalves. Int Rev Hydrobiol 85:529-541

Clarke KR (1993) Non-parametric multivariate analyses of changes in community structure. Aust J Ecol 18:117-143

Clarke KR, Gorley RN (2015) PRIMER v.7: user manual/tutorial. PRIMER-E, Plymouth

Clarke KR, Gorley RN, Somerfield PJ, Warwick RM (2014) Change in marine communities, an approach to statistical analysis and interpretation, 3rd edn. PRIMER-E, Plymouth

Commission European (2000) Directive 2000/60 EC of the European Parliament and of the Council of 23 October 2000 establishing a framework for community action in the field of water policy. Off J Eur Commun L 327(43):1-72

Dąbal A, Marciniak-Kowalska J (2011) Process of filling water reservoir in excavation of sulfur mine Machów. Pol J Environ Stud 4:57-61

Dalton LB, Cottrell S (2013) Quagga and zebra mussel risk via veliger transfer by overland hauled boats. Manag Biol Invasion 4:129-133

Davidson TM, Brenneis VEF, de Rivera C, Draheim R, Gillespie G (2008) Northern range expansion and coastal occurrences of the New Zealand mud snail Potamopyrgus antipodarum (Gray, 1843) in the northeast Pacific. Aquat Invasions 3:349-353

de Lange WJ, Genthea B, Hilla L, Oberholster PJ (2018) Towards a rapid assessment protocol for identifying pit lakes worthy of restoration. J Environ Manage 206:949-961

Dobson M (2013) Identifying invasive freshwater shrimps and isopods. The Freshwater Biological Assoc, Ambleside

Dumnicka E, Galas J (2006) Distribution of benthic fauna in relation to environmental conditions in an inundated opencast sulphur mine (Piaseczno Reservoir, southern Poland). Aquat Ecol 40:203-210

Elliott JM, Humpesch UH (2010) Mayfly larvae (Ephemeroptera) of Britain and Ireland, keys and a review of their ecology. The Freshwater Biological Assoc, Ambleside

Felter A, Stożek J, Socha M, Sokołowski J (2017) The sulphide waters in the area of Tarnobrzeg and the possibility of their development. Prz Geol 65:956-961

Fleeger JW, Thistle D, Thiel H (1988) Sampling equipment. In: Higgins RP, Thiel $\mathrm{H}$ (eds) Introduction to the study of Meiofauna. Smithsonian Institution Press, Washington DC, pp 115-125

Gammons CH, Harris LN, Castro JM, Cott PA, Hanna BW (2009) Creating lakes from open pit mines: processes and considerations, with emphasis on northern environments. Can Tech Rep Fish Aquat Sci 2826:106

Geller W, Schultze M, Kleinmann B, Wolkersdorfer E (2013) Acidic pit lakes, the legacy of coal and metal surface mines. Environmental Science and Engineering. Springer, Berlin, Heidelberg

Gołda T, Haładus A, Kulma R (2006) Rational water management in the post-mining areas of the Tarnobrzeg Sulfur Basin. Gospodarka Surowcami Mineralnymi 22:27-37 (in Polish)

Grabowski M, Jażdżewski K, Konopacka A (2007) Alien crustacea in Polish waters - Amphipoda. Aquat Invasions 2:25-38

Grabowski M, Bacela K, Konopacka A, Jażdżewski K (2009) Salinityrelated distribution of alien amphipods in rivers provides refugia for native species. Biol Invasions 11:2107-2117 
Grzybkowska M, Kurzawski M, Dukowska M (2012) Response of Chironomidae (Diptera) to impoundments in lowland streams. Fauna Norvegica 31:25-33

Gugel J (2001) Life cycles and ecological interactions of freshwater sponges (Porifera, Spongillidae) in the River Rhine in Germany. Limnologica 31:185-198

Hall MJ, Closs GP, Riley RH (2001) Relationships between land use and stream invertebrate community structure in a South Island, New Zealand, coastal stream catchment. N Z J Mar Freshw Res 35:591-603

Hammer UT (1986) Saline lake ecosystems of the world. Dr. W. Kunk Publishers, Dordrecht

Heling CL, Stelzer RS, Drecktrah HG, Koenigs RP (2018) Spatial variation of benthic invertebrates at the whole-ecosystem scale in a large eutrophic lake. Freshw Sci 37:605-617

Jellison R, Williams WD, Timms B, Alcocer J, Aladin NV (2008) Salt lakes: values, threats and future. In: Polunin NVC (ed) Aquatic Ecosystems. Cambridge University Press, Cambridge, pp 94-110

Jones FH (2008) Taxonomic sufficiency: the influence of taxonomic resolution on freshwater bioassessments using benthic macroinvertebrates. Environ Rev 16:45-69

Karatayev AR, Burlakova LE, Padilla D (2002) Impacts of zebra mussels on aquatic communities and their role as ecosystem engineers. In: Leppäkoski E, Gollasch S, Olenin S (eds) Invasive aquatic species of Europe, distribution, impacts and spread. Kluwer Academic Publishers, Dordrecht, pp 433-466

Kasprzak A, Juśko K, Motyka J (2016) Changes of chloride and sulfates concentration in the Vistula River from the Goczałkowice reservoir to the Skawa River. Zesz Nauk IGSMiE PAN 94:197-204

Kirmer A, Tischew S, Ozinga WA, von Lampe M, Baasch A, van Groenendae JM (2008) Importance of regional species pools and functional traits in colonization processes, predicting re-colonization after large-scale destruction of ecosystems. J Appl Ecol 45:1523-1530

Kobak J, Kakareko T, Poznańska M, Zbikowski J (2009) Preferences of the Ponto-Caspian amphipod Dikerogammarus haemobaphes for living zebra mussels. J Zool 27:229-235

Kobak J, Jermacz Ł, Płąchocki D (2014) Effectiveness of zebra mussels to act as shelters from fish predators differs between native and invasive amphipod prey. Aquat Ecol 48:397-408

Kornijów R, Kairesalo T (1994) Elodea canadensis sustains rich environment for macroinvertebrates. Verh Int Ver Theor Angew Limnol 25:2270-2275

Krebs CJ (2001) Ecology, the experimental analysis of distribution, abundance. Benjamin/Cummings, San Francisco

Kułakowski P (1994) Ionic composition of Vistula River in Cracow in the last 120 years. Symp Materials, Cracow, pp 84-87

Legendre P, Legendre L (1998) Numerical Ecology, 2nd edn. Elsevier, Amsterdam

Leuven RSEW, Brock TCM, van Druten HAM (1985) Effects of preservation on dry and ash-free dry weight biomass of some common aquatic macro-invertebrates. Hydrobiologia 127:151-159

Luek A, Rasmussen JB (2017) Chemical, physical, and biological factors shape littoral invertebrate community structure in coal-mining end-pit lakes. Environ Manage 59:652-664

Lund MA, McCullough CD (2011) Restoring pit lakes: factoring in the biology. In: McCullough CD (ed) Mine Pit Lakes: closure and management. Australian Centre for Geomechanics, Perth, pp 83-90

Machów Diving Base (2013) Map of the 'Machów' pit lake, scale 1:10000. www.lok-octopus.pl/baza-machow/. Accessed: 12 Feb 2013

Magurran AE (2004) Measuring biological diversity. Blackwell Publishing, Oxford

Marshall JE (1978) Trichoptera. Hydroptilidae. Royal Entomological Society of London, London
Marszelewski W, Dembowska EA, Napiórkowski P, Solarczyk A (2017) Understanding abiotic and biotic conditions in post-mining pit lakes for efficient management: a case study (Poland). Mine Water Environ 36:418-428

Mborah C, Bansah KJ, Boateng MK (2016) Evaluating alternate postmining land-uses: a review. Environ Pollut 5:14-22

McCullough CD, Van Etten EJB (2011) Ecological restoration of novel lake districts: new approaches for new landscapes. Mine Water Environ 30:312-319

Merritt RW, Cummins KW (1996) An Introduction to the Aquatic Insects of North America, 3rd edn. Kendall/Hunt Publ. Co., Dubuque

Mishra SK, Hitzhusen FJ, Sohngen BL, Guldmann JM (2012) Costs of abandoned coal mine reclamation and associated recreation benefits in Ohio. J Environ Manage 100:52-58

Moog O (2002) Fauna Aquatica Austriaca-catalogue for autecological classification of austrian aquatic organisms. Austrian Federal Ministry of Agriculture Forestry Environment and Water Management, Vienna (in German)

Mordukhay-Boltovskoy PD (1964) Caspian fauna in fresh waters outside the Ponto-Caspian Basin. Hydrobiologia 23:159-164

Nilsson AN (1996) Aquatic insects of North Europe. A taxonomic handbook, vol 1. Apollo Books, Stenstrup

Nilsson AN (1997) Aquatic insects of North Europe. A taxonomic handbook, vol 2. Apollo Books, Stenstrup

Olszewski K (1871) Chemical partition of well and river waters in Cracow. Jagiellonian University Press, Cracow (in Polish)

Paine RT (1994) Marine rocky shores and community ecology, an experimentalist's perspective. Ecology Institute, Nordbruite

Pardo A (2014) A scuba diving direct sediment sampling methodology on benthic transects in glacial lakes: procedure description, safety measures, and tests results. Environ Sci Pollut Res Int 21:12457-12471

Perán A, Velasco J, Millán A (1999) Life cycle and secondary production of Caenis luctuosa (Ephemeroptera) in a semiarid stream (Southeast Spain). Hydrobiologia 400:187-194

Poikane S, Johnson RK, Sandin L, Schartau AK, Solimini AG, Urbanič G et al (2016) Benthic macroinvertebrates in lake ecological assessment: a review of methods, intercalibration and practical recommendations. Sci Tot Environ 543:123-134

Polunin NVC (ed) (2008) Aquatic ecosystems. Cambridge University Press, Cambridge

Ricciardi A, Whoriskey FG, Rasmussen JB (1997) The role of the zebra mussel (Dreissena polymorpha) in structuring macroinvertebrate communities on hard substrata. Can J Fish Aquat Sci 5:2596-2608

Ruhí A, Boix D, Sala J, Gascón S, Quintana XD (2009) Spatial and temporal patterns of pioneer macrofauna in recently created ponds, taxonomic and functional approaches. Hydrobiologia 634:137-151

Schultze M, Pokrandt KH, Hille W (2010) Pit lakes of the Central German lignite mining district, creation, morphometry and water quality aspects. Limnologica 40:148-155

Siwik-Ziomek A, Brzezińska M, Lemanowicz J, Koper J, Szarlip P (2018) Biological parameters in technogenic soils of a former sulphur mine. Int Agrophys 32:237-245

Szmuc M, Madej K (2011) There was a sulphur! What is now? Górnictwo i Ekol 6:211-221 [In Polish]

Tachet H, Richoux P, Bournaud M, Usseglio-Polaterra P (2002) Freshwater Invertebrates, Systematic, Biology, Ecology. CNRS Editions, Paris (in French)

Vandenberg J, McCullough C (2017) Key issues in mine closure planning for pit lakes. In: Bolan NS, Kirkham MB, Ok YS (eds) Spoil to Soil: Mine Site Rehabilitation and Revegetation. CRC Press, Boca Raton 
Wallace ID (1981) A key to larvae of the family Leptoceridae (Trichoptera) in Great Britain and Ireland. Freshw Biol 11:273-297

Williams DD, Williams NE (1998) Aquatic insects in an estuarine environment, densities, distribution and salinity tolerance. Freshw Biol 39:411-421

Wolf B, Kiel E, Hagge A, Krieg HJ, Feld CK (2009) Using the salinity preferences of benthic macroinvertebrates to classify running waters in brackish marshes in Germany. Ecol Indic 9:837-847

Zar JH (2010) Biostatistical analysis, 4th edn. Prentice Hall, New York

Żurek R (2006) Chemical properties of the water in a flooded opencast sulphur mine (Piaseczno reservoir, southern Poland). Aquat Ecol 40:135-153
Żurek R (2013) Lakes in large scale open-pits in Poland. In: Geller W, Schultze M, Kleinmann R, Wolkersdorfer C (eds) Acidic pit lakes: the legacy of coal and metal surface mines. Environmental Science and Engineering. Springer, Berlin, Heidelberg, pp 291-314

Żurek R, Diakiv V, Szarek-Gwiazda E, Kosiba J, Wojtal AZ (2018) Unique pit lake created in an opencast potassium salt mine (Dombrovska pit lake in Kalush, Ukraine). Mine Water Environ $37: 456-469$ 